\title{
DETERMINAN PERSEPSI SUAMI TENTANG PENGGUNAAN ALAT KONTRASEPSI ANALISIS SDKI 2017
}

\author{
DETERMINATION OF HUSBAND PERCEPTION'S ABOUT \\ CONTRACEPTION : SDKI ANALYSIS 2017
}

\author{
Tri Kesuma Dewi ${ }^{1}$, Janu Purwono ${ }^{2}$, Ludiana $^{3}$ \\ 1,2,3 Akademi Keperawatan Dharma Wacana \\ email: trikesumadewi06@gmail.com
}

\begin{abstract}
ABSTRAK
Indonesia memiliki jumlah penduduk terbanyak ke empat didunia. Pertambahan penduduk yang tidak terkendali akan menyebabkan penurunan tingkat kesejahteraan. Pemerintah melakukan berbagai upaya untuk mengendalikan pertambahan penduduk tersebut salah satunya dengan penggunaan alat kontrasepsi. Berbagai factor yang mempengaruhi keberhasilan penggunaan alat kontrasepsi, salah satunya adalah persepsi suami. Penelitian ini bertujuan untuk mengetahui factor-faktor yang berhubungan dengan persepsi suami tentang penggunaan alat kontrasepsi. Metode yang digunakan dalam penelitian adalah kuantitatif deskriptif dengan pendekatan Analisis Data Sekunder (ADS). Data pada penelitian ini adalah data SDKI 2017 yang memenuhi kriteria penelitian yaitu sebanyak 9.940. Hasil analisa data menemukan bahwa terdapat hubungan yang signifikan antara pekerjaan, wilayah tempat tinggal, tingkat ekonomi dan tingkat pendidikan dengan persepsi suami tentang penggunaan alat kontrasepsi. Pada penelitian ini juga menemukan bahwa factor yang paling mempengaruhi persepsi suami adalah wilayah tempat tinggal dengan ods rasio 1,515. Informasi tentang pentingnya penggunaan alat kontrasepsi dapat dilakukan lebih baik tidak hanya di daerah perkoataan tetapi juga pada daerah pendesaan.
\end{abstract}

Kata kunci: persepsi, suami, alat kontrasepsi

\begin{abstract}
Indonesia has the fourth largest population in the world. Uncontrolled population growth will lead to a decrease in the level of welfare. The government has made various efforts to control the population growth, one of which is the use of contraceptives. Various factors influence the success of using contraceptives, one of which is the perception of the husband. This study aims to determine the factors related to the husband's perception of the use of contraceptives. The method used in this research is descriptive quantitative with the Secondary Data Analysis (ADS) approach. The data in this study were the SDKI 2017, which include in criteria its about 9,940 respondents. The results of data analysis found that there was a significant relationship between occupation, area of residence, economic level and education level with husbands' perceptions about the use of contraceptives. In this study also found that the factor that most influenced the husband's perception was the area of residence with an ODS ratio of 1.515. The government should reach all levels of society, whether living in urban or rural areas, in providing information about the use of contraceptives
\end{abstract}

Key word : perception, husband, contraception 


\section{PENDAHULUAN}

Indonesia berada di urutan ke-empat, sebagai negara yang memiliki jumlah penduduk terbanyak di dunia setelah China, India dan Amerika ${ }^{1}$. Indonesia mengalami peningkatan jumlah penduduk setiap tahunnya. Berdasarkan data yang ada pada Badan Pusat Statistik, disebutkan bahwa jumlah penduduk Indonesia pada tahun 2018 mencapai 265 juta penduduk dan pada tahun 2019 mencapai 268 juta lebih penduduk ${ }^{2}$.

Mengutip data tersebut, dapat kita lihat bahwa setiap tahun Indonesia mengalami jumlah penduduk sekitar 3 juta orang. Pertumbuhan penduduk ini harus di iringi dengan peningkatan kapasitas ekonomi yang baik, karena apabila tidak diiringi dengan pengikatan kapasitas ekonomi yang baik maka pertambahan penduduk akan menurunkan tingkat kesejahteraan masyarakat hal ini juga akan berakibat terhadap peningkatan angka kriminalitas dan kondisi lainnya seperti kondisi sosial dan kesehatan. Pemerintah berusaha untuk mengurangi laju pertumbuhan penduduk dengan menggalakkan program keluarga berencana melalui penggunaan alat kontrasepsi.

Cakupan penggunaan alat kontrasepsi secara nasional mencapai $75,88 \%$. Pada cakupan ini, dari seluruh provinsi di Indonesia yang berjumlah 33 provinsi ada 15 provinsi yang cakupannya masih berada di bawah cakupan nasional. Provinsi Bengkulu merupakan provinsi dengan jumlah cakupan tertinggi yaitu mencapai $87,70 \%$ sedangkan provinsi Papua menjadi provinsi dengan cakupan terendah, yaitu sebesar $67,15 \%^{3}$. Berdasarkan data tersebut terdapat $15,52 \%$ penduduk yang tidak pernah menggunakan alat kontrsepsi. Penggunaan alat kontrsepsi yang menjadi tolak ukur keberhasilan program keluarga berencana ini dipengaruhi oleh banyak faktor, salah satunya adalah persepsi suami tentang penggunaan alat kontrasepsi.

Pentingnya persepsi suami tentang KB akan menentukan penggunaan $\mathrm{KB}$ istri. Suami yang memiliki persepsi yang positif tentang penggunaan alat kontrasepsi akan mendukung istri, sehingga penggunaan alat kontrasepsi akan berhasil. . Hal ini dikarenakan di Indonesia memiliki kebudayaan dimana istri harus mengikuti apa yang dikatakan oleh suami. Pernyataan ini dibuktikan dengan beberapa penelitian yang menyebutkan adanya hubungan antara dukungan suami dan penggunaan IUD, salah satunya pada penelitian yang berjudul Faktor-faktor yang Mempengaruhi Minat Wanita Usia Sibir (WUS) terhadap Pemakaian Alat Kontrasepsi IUD di Klinik Keluarga Sembada Ngagglik Sleman ${ }^{4}$

\section{METODE}

Penelitian ini menggunakan metode penelitian kuantitatif deskriptif dengan pendekatan Analisis Data Sekunder (ADS). Analisis merupakan suatu metode yang memanfaatkan data sekunder sebagai sumber data utama. . Pada penelitian ini data yang digunakan 
adalah data Survey Demografi Kesehatan Indonesia 2017. Subyek pada penelitian ini adalah data yang sesuai dengan kriteri inklusi yaitu data yang memiliki kelengkapan. Kelengkapan data pada sampel ini, adalah apabila sampel tersebut memiliki semua data tentang variabel yang diteliti sehingga sampel yang digunakan pada penelitian ini berjumlah 9.940 responden.

\section{HASIL}

Karakteristik Responden

\section{Tabel 1 Karakteristik Responden}

\begin{tabular}{llll}
\hline Variabel & Kategori & $\mathbf{n}$ & $\mathbf{\%}$ \\
\hline Usia & Remaja Awal : 12-16 & 1 & 0,0 \\
& Remaja Akhir : 17-25 & 436 & 4,6 \\
& Dewasa Awal : 26-35 & 2.736 & 28,8 \\
& Dewasa Akhir : 36-45 & 3.517 & 37,1 \\
& Lansia Awal : 46-55 & 2.800 & 29,5 \\
\hline Tipe tempat tinggal & Kota & 4.917 & 51,8 \\
& Desa & 4.573 & 48,2 \\
\hline Pendidikan terakhir & Tidak bersekolah & 131 & 1,4 \\
& Pendidikan Primer & 2.832 & 29,8 \\
& Pendidikan Sekunder & 5.113 & 53,9 \\
& Pendidikan Tinggi & 1.414 & 14,9 \\
\hline Tingkat Ekonomi & Poorest & 2.044 & 21,5 \\
& Poorer & 1.970 & 20,8 \\
& Middle & 1.869 & 19,7 \\
& Richer & 1.840 & 19,4 \\
& Richest & 1.767 & 18,6 \\
\hline Pekerjaaan & Tidak bekerja minimal 1 tahun & 56 & 0,6 \\
& terakhir & & \\
& Professional, tecnical & 722 & 7,6 \\
& Manager dan administrasi & 193 & 2,0 \\
& Clerical & 567 & 6,0 \\
& Sales & 1.301 & 13,7 \\
& Service & 1.639 & 17,3 \\
& Agricultural worker & 2.689 & 28,3 \\
& Industrial worker & 2.269 & 23,9 \\
& Lainnya & 54 & 0,6 \\
\hline & & 9.490 & 100 \\
\hline
\end{tabular}

Tabel 2

Hasil uji bivariat

Hubungan persepsi suami tentang penggunaan alat kontrasepsi

\begin{tabular}{ccc}
\hline Persepsi suami & & Pvalue \\
\cline { 2 - 3 } tentang & Usia & 0,307 \\
penggunaan alat & Pekerjaan & 0,04 \\
kontrasepsi & Tempat tinggal & 0,00 \\
& Tingkat Ekonomi & 0,00 \\
& Pendidikan & 0,00 \\
\hline
\end{tabular}


Tabel 3

Hasil uji Multivariat

Nilai ods rasio

\begin{tabular}{lc}
\hline Variabel yang masuk uji multivariat & Nilai ods rasio \\
\hline Tempat tinggal & 1,515 \\
Tingkat ekonomi & 0,868 \\
Tingkat pendidikan & 0,598 \\
\hline
\end{tabular}

\section{PEMBAHASAN}

Hasil data dari penelitian ini, pada data ini terlihat bahwa usia dari responden sangat beragam, mulai dari 16 tahun sampai 55 tahun. Berdasarkan Undangundang perkawinan tahun 1974 Nomor 1 menyebutkan bahwa batas usia minimal pria menikah adalah usia 19 tahun ${ }^{5}$. Pada proses pertumbuhan dan perkembangan manusia, pria mengalami pubertas pada usia 14 tahun atau bahwa ada yang mengalaminya lebih dahulu. Menginjak usia dewasa pada laki-laki berkembangkanya alat kelamin sekunder yang ditandai dengan kemampuan testis (buah zakar) yang dapat menghasilkan sperma $^{6}$. Menurut agama islam usia baliq pada remaja pria ditandai dengan mengalami mimpi basah, pada penelitian 22.439 remaja pria dan wanita didapatkan hasil bahwa usia pertama remaja pria ejakulasi adalah pada usia 13,4 tahun ${ }^{7}$. Pada hasil penelitian ini usia termuda dari responden adalah 16 tahun yang masuk kedalam usia remaja awal. Pada usia ini pria sudah dapat membuahi sel telur dan dapat menyebabkan kehamilan, namun secara psikologis usia 16 tahun masih merupakan masa dimana anak masuk kedalam priode penemuan diri dan kepekaan sosial serta tahap pendidikan yang dimana pada usia ini anak masuk dalam masa sekolah menengah ${ }^{8}$.
Pada pria yang memiliki usia diatas 45 tahun akan mengalami penurunan kadar hormon testosteron yang akan mempengaruhi produksi sperma. Hubungan antara usia dengan tingkat fertilitas juga disebutkan dalam penelitian yang menyebutkan bahwa terdapat hubungan yang signifikan antara usia dengan tingkat kesuburan pria. Pada hasil penelitian ini dapat terlihat bahwa responden terbanyak berada pada usia yang produktif yaitu usia 36-45 tahun dimana pada usia tersebut kadar hormon testosteron mengalami puncaknya sehingga kemungkinan terjadinya kehamilan sangat tinggi sehingga diperlukan alat kontrasepsi untuk menghindari kehamilan ${ }^{9}$.

Pada data tempat tinggal, dapat terlihat bahwa jumlah responden yang tinggal dikota memiliki jumlah yang hampir sama dengan responden yang tinggal di desa. Hal ini menunjukkan bahwa penyebaran penduduk di Indonesia mulai tersebar secara merata.

Pada data tingkat pendidikan, responden terbanyak pada penelitian ini memiliki tingkat pendidikan menengah, baik menengah pertama ataupun sekolah menengah atas. Pada penelitian ini juga dapat dilihat bahwa masih ada responden yang tidak memiliki 
pendidikan. Hal ini sesuai dengan penelitian yang disebutkan oleh program penilaian pelajar internasional (PISA) yang menyebutkan bahwa Indonesia memegang peringkat 74 dari 79 negara didunia. Bila dibandingkan dengan negara Asia lainnya indonesia berada di urutan dibawah Vietnam ${ }^{10}$. Pada tabel terlihat tingkat ekonomi terbanyak adalalah tingkat ekonomi menengah kebawah dengan pekerjaan disektor pertanian. Penelitian ini juga menunjukkan bahwa responden terbanyak berada di Provinsi Jawa Barat. Banyaknya jumlah penduduk yang tidak diiringi dengan tingkat ekonomi yang memadai akan menyulitkan perencanaan dan pembelanjaan pemerintah ${ }^{11}$.

\section{Uji Bivariat}

Berikut ini adalah pembahasan dari masing-masing uji bivariat:

\section{a. Hubungan antara persepsi suami tentang penggunaan alat kontrasepsi adalah tanggung jawab istri dengan usia}

Penggunaan alat kontrasepsi adalah tanggung jawab suami dan istri, karena mereka berdualah yang menanggung akibat dan efek samping dari penggunaan alat kontrasepsi. Pentingnya dukungan suami terhadap pemilihan dari alat kontrasepsi dibuktikan dari penelitian yang menemukan bahwa terdapat hubungan antara peran suami terhadap pemilihan jenis alat kontrasepsi ${ }^{12}$. Usia adalah salah satu faktor yang mempengaruhi terciptanya persepsi terhadap suatu kejadian. Pada hasil penelitian ini, teori tersebut tidak terbukti karena pada penelitian ini hasil analisa statistik menunjukkan bahwa tidak terdapat hubungan antara persepsi suami dan usia. Penelitian lain, menunjukkan hal yang berbeda, penelitian lain ini menemukan bahwa terdapat hubungan antara usia dan persepsi suami dalam memberikan dukungan bagi istri dalam perawatan bayi $^{13}$.

\section{b. Hubungan antara persepsi suami tentang penggunaan alat kontrasepsi pekerjaan.}

Persepsi adalah sesuatu yang proses yang diawali dengan proses penginderaan. Pada proses penginderaan tersebut, seorang individu akan menyimpulkan stimulus apa yang diterima melalui alat indera. Hal inilah juga yang menyebabkan pekerjaan dapat mempengaruhi persepi seseorang. Hasil penelitian ini sesuai dengan dengan teori persepsi yang di sebutkan oleh Robbins yang menyebutkan bahwa pelaku persepsi dipengaruhi oleh karakteristik individu seperti motivasi, sikap, kepentingan atau minat, pengalaman dan pengaharapan. Faktor lain yang dapat menentukan persepsi adalah umur, tingkat pendidikan, latar belakang sosial ekonomi, budaya, lingkungan fisik, pekerjaan, kepribadian dan pengalaman hidup individu ${ }^{14}$.

\section{c. Hubungan antara persepsi suami tentang penggunaan alat kontrasepsi dengan wilayah tempat tinggal}

Berdasarkan hasil uji bivariat, didapatkan hasil bahwa terdapat hubungan antara persepsi suami tentang penggunaan alat kontrasepsi dengan wilayah tempat tinggal. Hasil 
penelitian ini mendukung apa yang disampaikan oleh Nazarea dan Pollnac yang telah melakukan penelitian dan menemukan bahwa varibel-variabel sosial ekonomi seperti pendidikan, usia, pekerjaan, tempat tinggal dan gender memiliki hubungan dengan berbagai persepktif yang berbeda ${ }^{15}$. Hasil penelitian ini juga di dukung dari hasil penelitian sebelumnya yang menyebutkan bahwa terdapat perbedaan persepsi antara masyarakat yang tinggal didaerah pesisir dan masyarakat yang tinggal diperkotaan. Penelitian sebelumnya ini menemukan bahwa masyarakat yang tinggal diperkotaan memiliki persepsi yang positif tentang penggunaan alat kontrasepsi lebih banyak dibandingkan dengan masyarakat yang tinggal di daerah pesisir ${ }^{16}$.

\section{d. Hubungan antara persepsi suami tentang penggunaan alat kontrasepsi dengan tingkat ekonomi}

Berdasarkan hasil uji bivariat, didapatkan hasil bahwa terdapat hubungan antara persepsi suami tentang penggunaan alat kontrasepsi dengan tingkat ekonomi.

Hasil penelitian ini sesuai dengan dengan teori persepsi yang di sebutkan oleh Robbins yang menyebutkan bahwa pelaku persepsi dipengaruhi oleh karakteristik individu seperti motivasi, sikap, kepentingan atau minat, pengalaman dan pengaharapan. Faktor lain yang dapat menentukan persepsi adalah umur, tingkat pendidikan, latar belakang sosial ekonomi, budaya, lingkungan fisik, pekerjaan, kepribadian dan pengalaman hidup individu ${ }^{16}$.

e. Hubungan antara persepsi suami tentang penggunaan alat kontrasepsi dengan tingkat pendidikan

Berdasarkan hasil uji bivariat, didapatkan hasil bahwa terdapat hubungan antara persepsi suami tentang penggunaan alat kontrasepsi dengan tingkat ekonomi.

Pada tabel diatas kita juga dapat melihat bahwa semakin tinggi tingkat pendidikan responden, hasil dari persepsi tentang penggunaan alat kontrasepsi semakin positif. Pendidikan yang tinggi memberikan pengetahuan yang lebih baik terkait penggunaan alat kontrasepsi dan peran suami dalam penggunaannya. Hal ini juga sejalan dengan penelitian yang menyebutkan bahwa semakin tinggi tingkat pengetahuan dan persepsi yang positif akan meningkatkan keikutsertaan suami terhadap program keluarga berencana ${ }^{17}$.

\section{Uji Multivariat}

Penggunaan alat kontrasepsi saat ini identik dengan wanita, karena penggunaannya lebih banyak adalah pihak istri. Hal ini sesuai dengan data yang ada di BKKBN yang menemukan metode penggunaan alat kontrasepsi adalah metode-metode yang digunakan oleh para wanita atau istri $^{18}$. Penggunaan alat kontrasesi adalah tanggung jawab bersama, baik suami dan istri. Suami memiliki peran penting dalam keberhasilan penggunaan alat kontrasepsi. 
Hal ini dapat kita lihat dari hasil penelitian ini, yang menemukan dari 9.490 responden, $35,8 \%$ diantaranya setuju bahwa penggunaan alat kontrasepsi adalah tanggung jawab istri dan suami tidak perlu tahu. Munculnya persepsi ini diperngaruhi oleh banyak fakor, secara teori dan penelitian persepsi diperngaruhi oleh karakteristik responden seperti usia, wilayah tempat tinggal, pekerjaan, tingkat ekonomi, pendidikan dan lain sebagainya. Penelitian ini pun menemukan hal yang sama bahwa persepsi suami tersebut dipengaruhi oleh wilayah tempat tinggal, pekerjaan, tingkat pendidikan dan tingkat ekonomi. Berdasarkan penelitian ini juga menemukan variabel yang paling mempengaruhi adalah wilayah tempat tinggal, masyarakat yang tinggal di daerah rural atau desa lebih banyak yang menganggap bahwa penggunaan $\mathrm{kb}$ hanya tanggung jawab istri. Hal ini bisa disebabkan oleh beberapa hal seperti minimnya informasi tentang alat kontrasepsi, minimnya jenis $\mathrm{kb}$ yang bisa digunakan oleh pria dan juga adanya nilai ekonomis yang lebih tinggi apabila istri menggunakan $\mathrm{kb}$ dibandingkan para suami. Penggunaan $\mathrm{kb}$ pada pria misalnya adalah $\mathrm{kb}$ mantap atau MOP. Penggunaan jenis ini hanya bisa dilakukan pada jenis pelayanan kesehatan yang lebih tinggi dari tingkat puskesmas sehingga sulit dijangkau. Hal lain yang menjadi penyebabnya adalah budaya patrilineal, dimana pada budaya ini pria memiliki dominasi terhadap keputusan yang diambil dan para wanita atau istri harus mengikuti keputusan tersebut. Perlu adanya peran serta semua pihak untuk dapat merubah persepsi pria/suami tentang penggunaan $\mathrm{kb}$, karena keberhasilan penggunaan $\mathrm{kb}$ adalah tanggung jawab suami dan istri. Suami memiliki peranan penting baik sebagai pengguna aktif $\mathrm{kb}$ misalnya atau sebagai motivator istri untuk menggunakan alat kontrasepsi yang aman dan nyaman.

\section{KESIMPULAN}

Terdapat hubungan antara persepsi suami tentang penggunaan alat kontraspesi dengan pekerjaan, wilayah tempat tinggal, tingkat pendidikan dan tingkat ekonomi. Pada factor-faktor tersebut, variabel yang mempunyai hubungan yang paling kuat adalah wilayah tempat tinggal dengan ods rasio 1,515. Bagi pemerintah hendaknya memberikan informasi yang efektif terkait alat kontrasepsi tidak hanya pada masyarakat perkotaan tetapi juga masyarakat yang tinggal didesa.

\section{DAFTAR PUSTAKA}

1. Worldmeter. (2020). Countries in The World by Population (2020). dikutip dari https://www.worldometers.info pada 1 Juni 2020

2. Badan Pusat Statistik. (2020). Perencanaan Pembangunan. Dikutip dari https://www.bps.go.id/indikator/indi kator/view_pada 1 Juni 2020

3. Pusat Data dan Informasi. (2014). Situasi dan Analisis Keluarga Berencana. Jakarta:

Kementerian Kesehatan RI

4. Retno, R.S., Wulandari, S., Fitriani, A. (2019). Faktor-faktor yang Mempengaruhi Minat Wanita Usia Subur (WUS) terhadap Pemakaian Kontrasepsi IUD 
di Klinik Keluarga Sembada Ngagklik Sleman. Jurnal Kesehatan Karya Husada Vol.7 No.1

5. Hadiansyah, D. (2018). Falsafah Keluarga. Jakarta: Elex Media Komputindo

6. Watiniyah, B \& Ali, M (2017). Hadiah Pernikahan Terindah Menuju Sakinah Mawaddah wa rahmah. Jakarta: Kaysa Media

7. Brix, N., Ernst, A., Lauridsen, L. L. B., Parner, E., Støvring, H., Olsen, J., Henriksen, T. B., \& RamlauHansen, C. H. (2019). Timing of puberty in boys and girls: A population-based study. Paediatric and Perinatal Epidemiology, 33(1), 70-78.

https://doi.org/10.1111/ppe.12507

8. Muriah, S \& Wardan. (2020). Psikologi Perkembangan Anak dan Remaja, Jakarta: Literasi Nusantara

9. Sengupta, P., Dutta, S., \& Krajewska-Kulak, E. (2017). The Disappearing Sperms: Analysis of Reports Published Between 1980 and 2015. American Journal of Men's Health, 11(4), 1279-1304. https://doi.org/10.1177/1557988316 643383

10. CNN Indonesia. (2020). Target Pendidikan Indonesia 2035 Jauh dibawah rata-rata OECD. dikutip darihttps://www.cnnindonesia.com/ nasional/20200508172350-20-

501459/target-pendidikanindonesia-2035-jauh-di-bawah-ratarata-oecd pada tanggal 25 Desember 2020

11. Wardhana, A., Kharisma, B., \& Noven, S. A. (2020). Dinamika Penduduk Dan Pertumbuhan Ekonomi Di Indonesia. Buletin Studi Ekonomi, 25(1), 22. https://doi.org/10.24843/bse.2020.v 25.i01.p02

12. Utama, J. E. P., Sari, R., \& Ikhtiarini, E. (2016). Hubungan Peran Suami Terhadap Pemilihan Jenis Alat Kontrasepsi Kb Pada Ibu
Di Kelurahan Kebonsari Kabupaten Jember. Jurnal Ilmiah Kesehatan Media Husada, 5(1), 49-57. https://doi.org/10.33475/jikmh.v5i1. 125

13. Pramutasari, L.S., Indriyani, D., Handayani, L,T. (2014). Hubungan Status Usia dengan Persepsi Suami dalam Memberikan Dukungan Bagi Istri pada Perawatan Bayi Baru Lahir di Ruang Bersalin RSD Balung Jember. Naskah Publikasi dikutip dari http://digilib.unmuhjember.ac.id pada tanggal 26 Desember 2020

14. Robbins, S.P dan Judge, T. (2013). Organizational Behavior, New Jersey: Prentice Hall

15. Dahliah. (2020). Globalisasi Sumber Daya Alam, Lingkungan dan Kemiskinan. Tasikmalaya: Edu Publisher

16. Taufik, M., Salawati, T., Kesehatan, F., Universitas, M., Semarang, M., \& Subur, P. U. (2015). DI KABUPATEN DEMAK ( Studi Pada Masyarakat Pesisir Dan Masyarakat Kota di Kabupaten Demak ) PUBLIC PERCEPTION OF MEN KB IN DEMAK ( Studies in Society and Society of Coastal Cities in Demak ) Program Keluarga Berencana di Berdasarkan data Badan Pusat Desa. 10(2), 35-44.

17. Sirait. (2018). Hubungan Perspesi dan Pengetahuan Suami dengan Keikutsertaan Menjadi Akseptor KB MOP di RSUD DR.H Kumpulan Pane Tebing Tinggi Tahun 2018. Naskah Publikasi dikutip dari http://repo.poltekkesmedan.ac.id/jspui/bitstream/123456 789/797/1/JURNAL\%2

0BUK\%20suri.pdf pada tanggal 26 Desember 2020

18. BKKBN. (2014). Kebijakan Teknis KB dan Kesehatan Reproduksi.Jakarta: BKKBN 
Wacana Kesehatan Vol. 6, No. 1, Juli 2021 